\title{
"The integration of Management Accounting Practices as an innovative strategy towards sustaining small businesses operating in eThekwini metropolitan, South Africa"
}

$\begin{array}{ll} & \text { Mbali Portia Msomi (D https://orcid.org/0000-0002-0825-1854 } \\ & \text { Musawenkosi Ngibe (D https://orcid.org/0000-0002-4954-1460 } \\ \text { Luyanda Loraine Bingwa }\end{array}$

Mbali Portia Msomi, Musawenkosi Ngibe and Luyanda Loraine Bingwa (2020). The integration of Management Accounting Practices as an innovative strategy ARTICLE INFO towards sustaining small businesses operating in eThekwini metropolitan, South Africa. Problems and Perspectives in Management, 18(3), 268-281. doi:10.21511/ppm.18(3).2020.23

DOI http://dx.doi.org/10.21511/ppm.18(3).2020.23

RELEASED ON Monday, 21 September 2020

RECEIVED ON

Friday, 05 June 2020

ACCEPTED ON

Wednesday, 09 September 2020

\section{$((c)) E Y$}

LICENSE

This work is licensed under a Creative Commons Attribution 4.0 International License

JOURNAL

"Problems and Perspectives in Management"

ISSN PRINT $1727-7051$

ISSN ONLINE $1810-5467$

PUBLISHER

LLC "Consulting Publishing Company "Business Perspectives"

FOUNDER

LLC "Consulting Publishing Company "Business Perspectives"

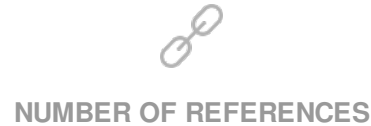

61

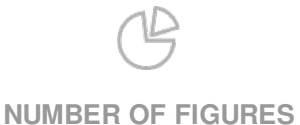

11
韺

NUMBER OF TABLES

0

(c) The author(s) 2022. This publication is an open access article. 


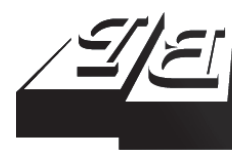

\section{BUSINESS PERSPECTIVES}

LLC "CPC "Business Perspectives" Hryhorii Skovoroda lane, 10, Sumy, 40022, Ukraine www.businessperspectives.org
Received on: $5^{\text {th }}$ of June, 2020 Accepted on: $9^{\text {th }}$ of September, 2020 Published on: $21^{\text {st }}$ of September, 2020

(C) Mbali Portia Msomi, Musawenkosi Ngibe, Luyanda Loraine Bingwa, 2020

Mbali Portia Msomi, M.Sc., Lecturer, Management Accounting Department, Faculty of Accounting and Informatics, Durban University of Technology, South Africa.

Musawenkosi Ngibe, Ph.D., Lecturer, Information and Corporate Management Department, Faculty of Accounting and Informatics, Durban University of Technology, South Africa. (Corresponding author)

Luyanda Loraine Bingwa, M.Sc., Lecturer, Information and Corporate Management Department, Faculty of Accounting and Informatics, Durban University of Technology, South Africa.

This is an Open Access article, distributed under the terms of the Creative Commons Attribution 4.0 International license, which permits unrestricted re-use, distribution, and reproduction in any medium, provided the original work is properly cited.

Conflict of interest statement: Author(s) reported no conflict of interest
Mbali Portia Msomi (South Africa), Musawenkosi Ngibe (South Africa),

Luyanda Loraine Bingwa (South Africa)

THE INTEGRATION

OF MANAGEMENT ACCOUNTING

PRACTICES AS AN INNOVATIVE STRATEGY TOWARDS SUSTAINING SMALL BUSINESSES OPERATING IN ETHEKWINI METROPOLITAN, SOUTH AFRICA

\begin{abstract}
The adoption of Management Accounting Practices (MAPs) has been acclaimed for providing positive administrative and strategic influence on large organizations, and are understood to play an integral part in decision-making. However, SMEs are operating in a turbulent environment, they are now challenged to effectively utilize the embedded MAPs to strengthen their strategic business approaches to maintain their sustainability and survival. Therefore, this study seeks to explore the challenges of integrating the adopted MAPs as an innovative strategy towards sustaining small businesses. The research sample consisted of 120 manufacturing SMEs operating in eThekwini metropolitan South Africa. A nonprobability convenience sampling technique and a quantitative questionnaire were utilized to identify and collect the data from the sampled population. The results of the study indicated that amongst other critical factors, lack of education and training of owner/manager and shortage of skills were the contributory factors influencing the integration of MAPs as an innovative strategy towards SMEs' sustainability. The study results further revealed that there are a variety of other challenges hindering SMEs from utilizing MAPs as an innovative strategic tool and those were the enterprise age and years in operation, lack of government business incubation and technology adoption. These contributory factors were identified as necessary aspects that SMEs needed to align and iron out before integrating MAPs as an innovative strategic tool.
\end{abstract}

\section{Keywords \\ Management Accounting Practices, innovation, entrepreneurship, sustainability, small businesses}

JEL Classification

M19, L22

\section{INTRODUCTION}

Rooted in providing formal and informal employment, the key to instigating and producing innovative products, and essential in supplementing the economic growth of South Africa, small and medium enterprises (SMEs) are recognized for their relentless contribution towards the economy of South Africa, with specific reference to SMEs operating in eThekwini metropolitan (Jili, Masuku, \& Selepe, 2017; Ngibe \& Lekhanya, 2019). Their ability to generate wealth and further play a critical role in the socio-economic stability of South Africa shows the magnitude role and potential these small businesses have towards resuscitating and strengthening the economy of the nation (Fin24, 2017; OECD, 2017). These small businesses further assume an indispensable role in importing and exporting merchandise, promoting internationalization, and lure possible international investors 
(Zafar \& Mustafa, 2017). However, SMEs are faced with both internal and external challenges that weigh heavily on their quest for survival in this congested yet turbulent business environment. The mortality rate of SMEs has been characterized by many factors, including lack of capital, poor access to finance, lack of management, inability to budget, lack of innovative business ideas and marketing strategies (Turyahikayo, 2015; Bhoganadam, N. Rao, \& D. Rao, 2017; Nnawetanma, 2020).

Many scholars have credited the incapability and shortage of SMEs' owners' skills as the contributory factor to SMEs' inability to adopt Management Accounting Practices (MAPs) to strengthen their business operations (Msomi, Ngibe, \& Nyide, 2019). Furthermore, factors such as the availability of scarce resources, firm size, changes in firm structure, lack of education by the owner, technological advancements, competition, and networking with other businesses significantly influence the adoption of MAPs by SMEs (Otley, 2016). According to CIMA (2009), integrating MAPs not only provides effective use of financial and non-financial information but also improves the strategic focus, which is embedded in the decision-making process and ultimately optimizes the business performance. The inadequate adoption of innovative MAPs by small businesses negatively affects the decision-making processes and suppresses business performance (Malagueño et al., 2018). This not only possesses a great threat towards the internal functions of the business but also impedes the businesses' ability to engage with other external stakeholders and effectively shortens the business life cycle (Pavlatos \& Kostakis, 2015). The recent economic crisis escalation has affected all types of businesses globally, with SMEs having no exception, forcing them to formulate or enhance innovation strategies to optimize the businesses' objectives (Pavlatos \& Kostakis, 2018). Nevertheless, large organizations conventionally incorporate innovative strategies within their management control systems, which improve their competitive edge and sustainability compared to SMEs (Pedroso \& Gomes, 2020). Small businesses need to develop and sustain their business performance, and innovative MAPs need to be an integral part of the organizational processes (Hussein, 2018; Johnstone, 2020). Therefore, this study aimed to determine the challenges of integrating MAPs as an innovative strategy towards sustaining small businesses. The study adopted a quantitative research approach, using a non-probability sampling technique (convenience sampling) to determine the sample size.

\section{LITERATURE REVIEW}

\subsection{Current status of small businesses in South Africa}

Small businesses are commonly referred to as small and medium enterprises (SMEs) or interchangeably to small, micro, and medium enterprises (SMMEs) with categories such as size, fiscal performance, and expansion activities that can be used to classify them depending on the country's regulations (Keskin \& Șentürk, 2010). For most small enterprises, the effort of job creation and contribution towards the gross domestic product (GDP) is comprehensively promoted across all nations (Abor, 2015; Karedza, Sikwila, Mpufu, \& Makurumidze, 2014; Hoeppli, 2012; Mahembe, 2011). This implies that for developing and developed countries, these enterprises substantially influence the sustainability of the economy. In South Africa, small businesses are clas- sified as having less than 50 full-time employees, making less than 2 million Rands worth of revenue, and possess less than 10 million worth of assets (National Small Business Act 102 of 1996). The South African Government recognizes these types of enterprises as the pillars of the economy, promoters of reducing unemployment, creators of innovation and sustainability (Bureau of Economic Research, 2016; International Leadership Development Programme, 2014). These small businesses in South Africa are recognized and constitute over 36 percent towards the national economy worldwide (Chugtai \& Alam, 2014; Jere et al., 2014). With the high unemployment rate amongst South Africans, government and supporting agencies spur small businesses by assisting in funding the registration, working capital, mentorship, training, acquisition of resources, and other necessities essential to sustain these enterprises (SEDA, 2018; Statistics South Africa, 2018). The promotion of new SMEs opens 
opportunities for innovative product developments, better use of ICT, the stimulus of innovation, and a competitive edge that will sustain the economy (Abor \& Quartey, 2010).

\subsection{Challenges facing small businesses}

Although small businesses are recognized globally as a striving economic catalyst, these entities suffer voluminous challenges that hinder their survival strategies (Timmis, 2019). South African small businesses incur the highest business failure rates amongst other forms of entities, this is reflected by their fatality rates during the inception period and lack sustainability due to numerous challenges (Msomi et al., 2019). The prevailing challenges established amongst small businesses were identified amongst scholars as but not limited to firm age, size, lack of education, government interventions, access to finance, ICT, lack of adequate adoption of MAPs, and other factors (Ngibe \& Lekhanya, 2019; Msomi et al., 2019; Zondo, 2016; AgwaEjon \& Mbohwa, 2015; Kusi-Sarpong et al., 2015). Other scholars have also indicated that great internal hindrances affect SMEs survival capabilities such as mismanagement of funds, inadequate experience by the business owners, lack of capital resources, and lack of accounting background to run the businesses (Oyelana \& Smith, 2015; Tengeh, 2015; Trust, 2015). These factors are still of great concern as they are perceived as the major catalyst for business failure, suppressing small businesses in South Africa (Department of Trade and Industries, 2018).

\subsection{Management Accounting Practices (MAPs) adoption by small businesses}

Management Accounting Practices (MAPs) are essential techniques that require the use of financial and non-financial information by owners/managers or other relevant decision-makers to facilitate the decision-making process (Armitage, Webb, \& Glynn, 2016). However, Msomi et al. (2019) pointed out that the adoption of MAPs amongst SMEs compared to large firms is diverse, as large firms have complex structures that allow better integration of MAPs than smaller firms. Otley (2016) urged that no single or uniform MAP can be incorporated to suit all firms, since each firm has its characteristics that separate them amongst other firms. Therefore, management accounting research is a great concern especially the MAPs adoption within the SMEs' sectors. Scholars have invested in the following areas of research about SMEs: factors influencing the adoption of MAPs, the impact of adopting MAPs on the business performance; use of ICT towards enhancing MAP adoption; challenges of adopting MAPs, while not much emphasis has been placed on exploring the integration of MAPs as an innovative strategic tool for sustaining SMEs.

Evidence suggests that MAPs are crucial in running an effective business and provide small business managers with relevant financial and non-financial information, which helps to facilitate the decision-making process that will make the business profitable and ensure that it becomes more sustainable. Furthermore, information received from MAPs guides small business managers' actions and helps reduce the likelihood of failure (Maziriri \& Mapuranga, 2017). In contrast, the forever changing business environment, which is due to technological advancement, changes in the economy, and competition, requires small businesses to transition to sophisticated MAPs to match the newer business dynamics needs (Abel-Maksoud, 2011; Surnani, 2013). However, most of these small businesses have little or no comprehension of adopting (MAPs) in their business operations, which impends on their survival tactics (Ayandibu \& Houghton, 2017; Amoak, 2013). MAPs are wellknown for providing owners/managers and other decision-making stakeholders with relevant, reliable, and accurate information that heavily influences their business operations and performance (Nandan, 2010; CIMA, 2015). This implies that integrating MAPs within the business operations is essential to promote business growth, competitive edge, product innovations, or diversifications and sustain business activities (Ahmad \& Mohamed Zabri, 2015). Therefore, small enterprises' application of MAPs stimulates innovative strategies that can help curb the dreadful business failure of such enterprises. 


\subsection{Innovation as a strategic tool for small business}

Small businesses face challenges with developing innovative ideas due to limited resources which impede their ability to compete in a global economic structure. Thus, for the sustainability of these small businesses, it is necessary to use strategic innovative tools to meet consumers' ever-changing needs (Uturyte-Vrubliauskiene \& Linkevicius, 2011; Halme \& Korpela, 2014). The literature reveals that for the successful adoption of innovation strategies, small business managers not only need to be conscious of risks involved but also need to ensure that managers fully support strategies chosen to enhance small business competitiveness (Razavi \& Attarnezhad, 2013). However, this is not possible in the absence of identification of innovation needs and possible causes of the failure of small businesses, which from literature, ineffective marketing strategies, lack of financial assistance, and education form part of the reasons for the failure of small businesses (Cant, 2012). Amongst other competencies that a manager needs are the organizational intelligence, which means the manager needs to be analytic in terms of analyzing the competitors, be able to identify market trends, be a visionary, creative, and competent in the creation of innovative initiatives (Razavi \& Attarnezhad, 2013). Kogabayev and Maziliauskas (2017) indicate that addressing the skill gap requires training not only to ensure the sustainability of small businesses but also to improve their competitive edge. Fischer and Rohde (2013) and Dibrov (2015) attest that the successful adoption of innovation relies on the level of education; thus, enhancement education through the stimulation of entrepreneurial activities, creation of innovative culture, and ensuring maximum management support is crucial. Therefore, continuous strategic innovation is crucial in gaining competitive advantage, and the firm's innovativeness is closely related to the ability to keep up with technological changes (Zawawi, Wahab, AL-Mamun, Yaacob, Samy, \& Fazal, 2016). Ahmad and Mohamed Zabri (2015) attest that technological advancement has influenced how business is conducted, and staying competitive requires that SMEs rethink efficient and innovative ways of conducting business through the integration of technology.

\subsection{Sustainability of small businesses}

Sustainable innovation is a problem-solving approach that requires small business managers to have the willingness, innovative capacity, and knowledge to identify the problem and develop innovative solutions. Furthermore, sustainability is a key driver of innovation; it is a vital component that seeks to reiterate the importance of small businesses' sustainability (Stock, Obenaus, Slaymaker, \& Seliger, 2016). Small business sustainability is concerned with managing social, environmental, and financial demands to ensure ongoing success. While maintaining the current supply to their customer needs, the business should continuously develop future profitability strategies and continue to exist regardless of challenges (Banker, Mashruwala, \& Tripathy, 2014; Hansen \& Schaltegger, 2016; Pantelica, Sakalb, \& Zehetner, 2016). The literature reveals a gap between innovation and sustainability, which requires the adoption of effective innovative strategies, as innovation is linked to the sustainability of small businesses. With the increasing competition amongst small businesses, it has become crucial to utilize innovation in improving products and firm performance ( $\mathrm{Wu}$, Liao, Tseng, \& Chou, 2015).

Kraus (2017) opines that sustainability not only entails that a business should ensure profitability but also ensures that there is visible growth while meeting the needs of society. Banker, Mashruwala, and Tripathy (2014) attest that for a business to be sustainable, it would have been because of the adoption of effective strategies that seek to ensure that market share increases. The organization continues to successfully operate even with the existing market threats and the continuous ability to respond to market needs in the long term.

\subsection{Entrepreneurship towards the sustainability of the small business}

An entrepreneur is a person who identifies the niche opportunity, then comes up with innovative ideas to address the need (Gakure, Ngugi, Waititu, \& Keraro, 2013). For the sustainability of small businesses, there is a need for entrepreneurial education as it equips small business own- 
ers with the knowledge and skills needed to critically think in alignment to the entrepreneurial setting (Reyad, Al-Sartawi, Badawi, \& Hamdan, 2019). In contrast, the literature reveals no relationship between entrepreneurial education and small business sustainability as the requirements for entrepreneurship are not clearly stated nor linked to small business success (Chell, 2013; Morale \& Marquina, 2013). However, to ensure that entrepreneurship education yields expected results, which will, in turn, ensure the sustainability of small businesses, managers need to identify skills required and conduct training that will equip them with the necessary skills (Turton \& Herrington, 2012).

\section{METHODS}

To generate insight into adopting MAPs as an innovative strategy towards sustaining small businesses, a quantitative research approach was adopted for this study. The target population for this study consisted of 120 small businesses situated in the eThekwini metropolitan. A non-probability sampling technique (convenience sampling) was used to determine the sample size for this study.

\subsection{Questionnaire design}

A questionnaire was designed through the objectives of the study and literature review to meet the study objectives. Questionnaires in a Likert scale form were utilized to collect data from the target population to enable the researcher to ascertain critical factors affecting the adoption of MAPs as an innovative strategy towards sustaining small businesses.

\subsection{Validity and reliability}

To ensure the validity and reliability of the collected data, the questionnaire sample was sent to a research expert to check whether the questionnaire covered all the variables and had no ambiguity. To achieve the study, aim and objective, and to check reliability, the instrument was piloted to $10 \%$ of the sample size, which ensured the instrument's quality. Data collected from questionnaires were coded and analyzed using SPSS version 26.0. Descriptive analysis was conducted and shown in frequencies and percentages to determine the level of agreement and disagreement of the respondent's challenge affecting the utilization of MAPs as an innovative strategic tool to acquire sustainable business growth.

\section{RESULTS AND DISCUSSIONS}

This section provides a descriptive analysis and discussion of the findings of the study. The findings are, therefore, presented in Figures 1-11.

As reflected in Figure 1, most respondents, 58 (38.7\%) and 41 (27.3\%), agreed and strongly agreed that the adoption of MAPs is influenced by the enterprise age and years of operation. Fewer respondents (19.4\%) disagreed with the statement, while only $22(14.7 \%)$ of the respondents were neutral. Based on these findings, it is clear that the respondents strongly believed that enterprise age and years of being in operation significantly influenced the adoption of MAPs. These findings indicate a much-uninformed perception and misconception about adopting MAPs, as they can be

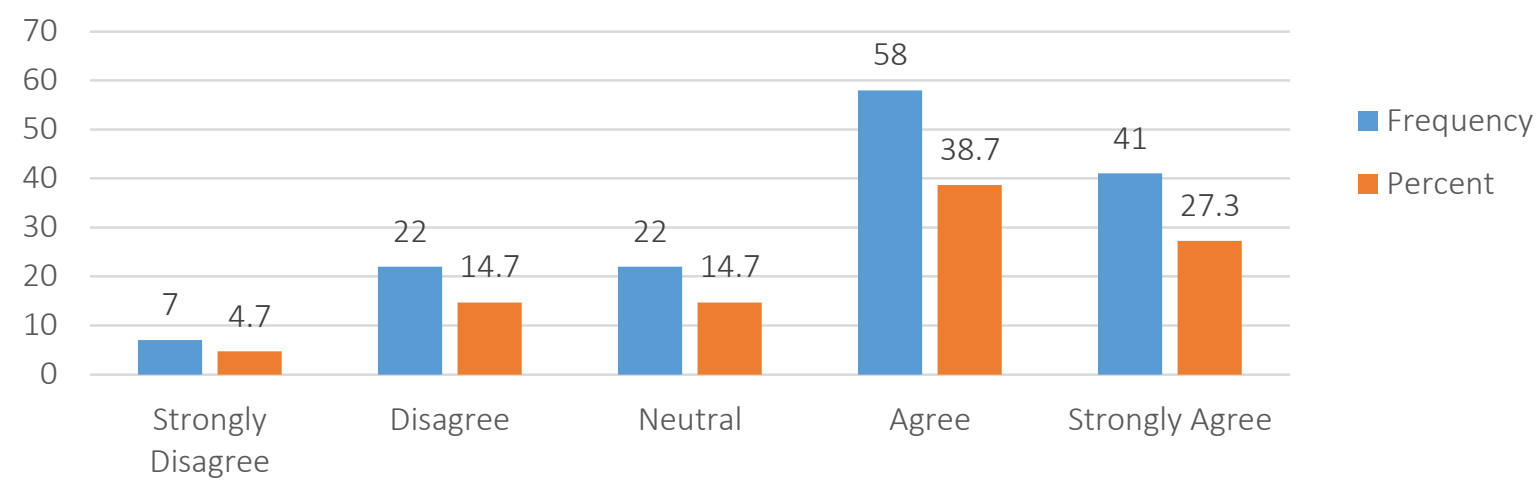

Figure 1. The adoption of MAPs is influenced by the enterprise age and years of being in operation 


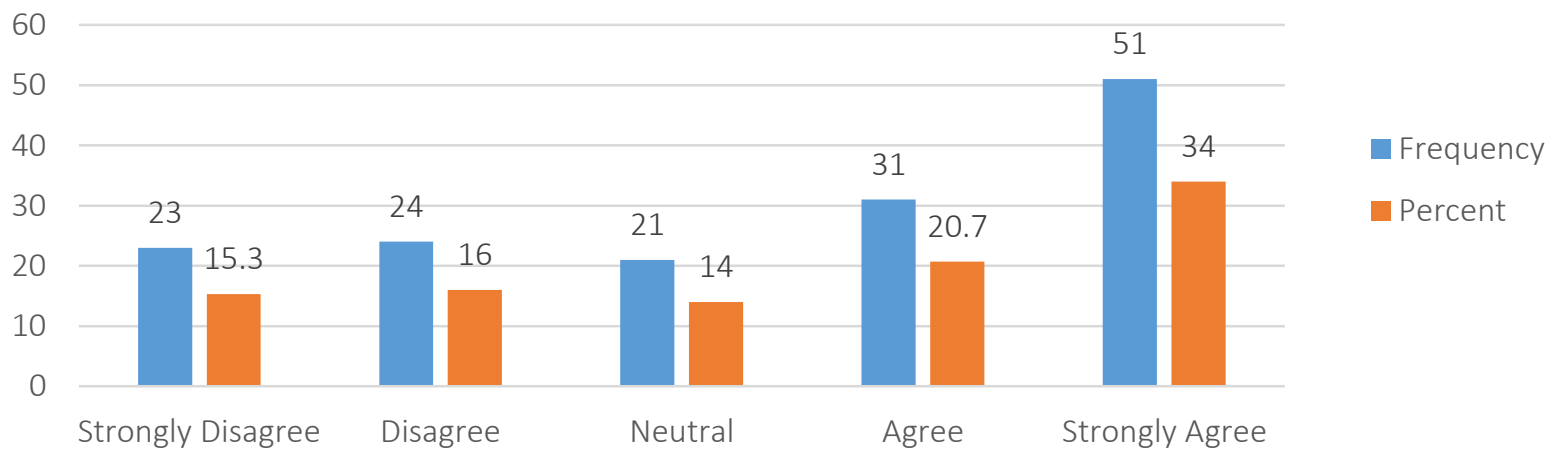

Figure 2. Lack of education and training of owner/manager influences the adoption of MAPs

adopted and utilized at any developmental stage or life cycle of the enterprise. To some extent, it can be argued that the instabilities of capital influenced the respondents' perceptions that new enterprises have, and the adoption of MAPs might prove costly to newly established enterprises.

The results displayed in Figure 2 show that 51 $(34.0 \%)$ and $31(20.7 \%)$ of the respondents agreed and strongly agreed, respectively, that a lack of education and owner/manager training influences the adoption of MAPs. A few respondents, 24 (16\%) and $23(15.3 \%)$, disagreed and strongly disagreed with the statement, while only $21(14.0 \%)$ of the respondents were neutral. These findings indicate that most (54.7\%) the respondents viewed and believed that the lack of education and training is one of the contributory factors influencing the adoption of MAPs within SMEs. These findings also reflect that, without proper education and understanding of MAPs and their full potential, owners and managers will have an imprecise understanding of which MAPs would be best suitable and beneficial to their business operations and how they can integrate them into their business operations.
As reflected in Figure 3, a significant number of the respondents, $64(42.7 \%)$ and 62 (41.3\%), agreed and further strongly agreed that a shortage of skills is one of the challenges managers and owners face in adopting MAPs. This means that $84 \%$ of the respondents viewed and believed that, if all managers and owners of SMEs had relevant skills, the adoption of MAPs would have been customary in almost all SMEs, with specific reference to the eThekwini metropolitan. Very few respondents $(10 \%)$ disagreed with the statement, while only $9(6.0 \%)$ were neutral. These findings add to the conundrum of various critical challenges that stagnant business innovation and SMEs' subsequent business sustainability. Without the necessary knowledge, understanding, and skills, SMEs' owners will find it a daunting task to utilize MAPs to strengthen their strategic business approaches and improve business operations.

Based on Figure 4, 31 respondents (20.7\%) strongly disagreed, and 28 (18.7\%) disagreed that lack of government business incubation influences the adoption of MAPs. These figures are closely

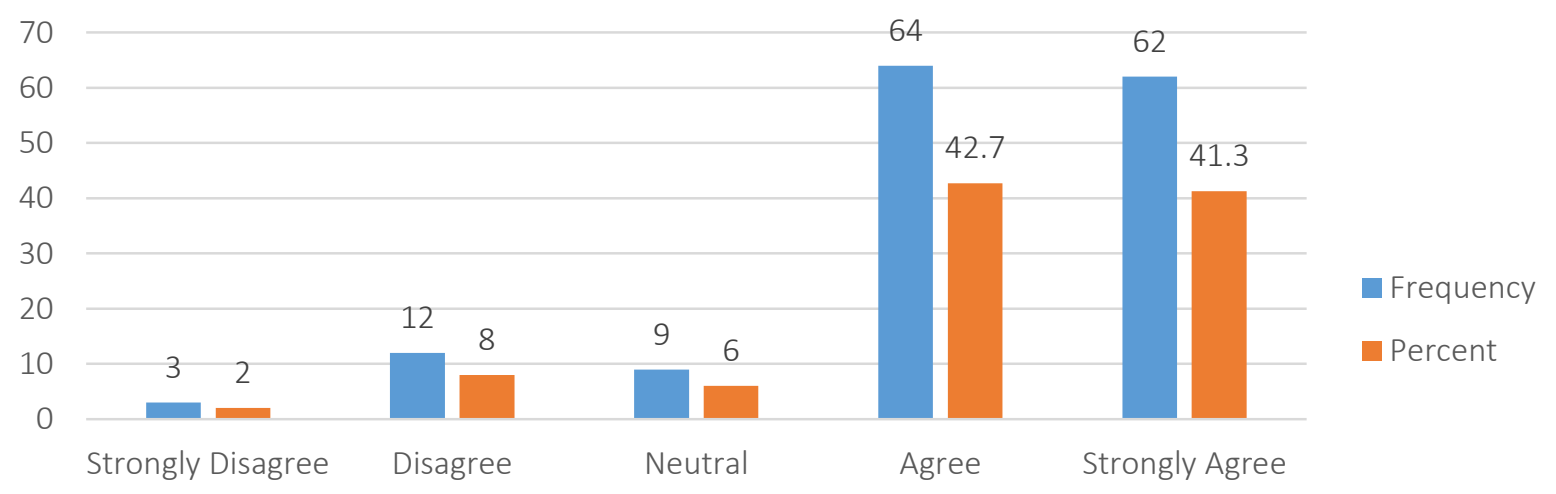

Figure 3. Shortage of skills influences the adoption of MAPs in business operations 


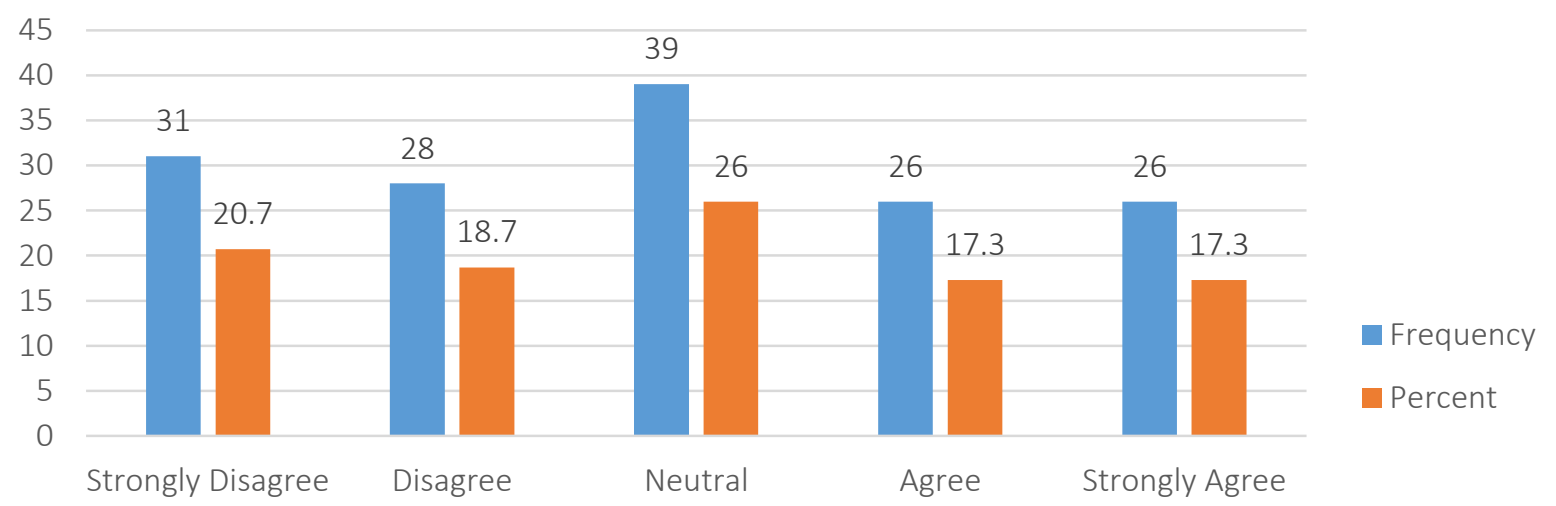

Figure 4. Lack of government business incubation influences the adoption of MAPs

matched by respondents who agreed (34.6\%) with the statement, and 39 (26\%) respondents being neutral. Given these findings, it is safe to say that the respondents were not entirely certain about the government business incubations formulated to support and assist with the adoption of MAPs and any related support. Therefore, it is clear that SMEs in eThekwini metropolitan are unaware of the services provided by the government in support of small businesses, particularly with the adoption of MAPs.

As reflected in Figure 5, most respondents, 63 (42.0\%) and 31 (20.7\%), strongly agreed and agreed that technology adoption influences the adoption of MAPs. Fewer respondents, 22 (14.7\%) and $14(9.3 \%)$, disagreed with the statement, while $20(13.3 \%)$ were neutral. These findings indicate that most respondents viewed technology as a key enabler to the adoption of MAPs. This would mean that, for SMEs in EThekwini Metro to maintain a competitive edge and acquire innovation, technology and MAP adoption should be synchronized.
As reflected in Figure 6, a significant number of the respondents, 60 (40.0\%), strongly agreed, and 45 (30.0\%) further agreed that technology adoption and usage of MAPs are key innovative strategies for business growth. Few respondents, 25 (16.7\%) and $8(5.3 \%)$, disagreed with the statement, while only $12(8.0 \%)$ respondents were neutral. As per the findings of this research study, the alignment of technology and the adoption of relevant MAPs were considered fundamental business growth strategies. This means that, for managers and owners to sustain business growth, they will need to seek advanced technology to match the integrated MAPs that would be aligned to the enterprise operations.

As reflected in Figure 7, 56 (37.3\%) and 38 (25.3\%) of the respondents agreed and further strongly agreed that adopting MAPs impedes business innovation. A fewer number of the respondents, 31 (20.7\%) and 13 (8.7\%), disagreed and strongly disagreed, respectively, with the statement, while $12(8.0 \%)$ were neutral. These findings indicate and mean that more than $60 \%$ of the respondents believed that an enterprise's inability to adopt MAP might pose a detrimental

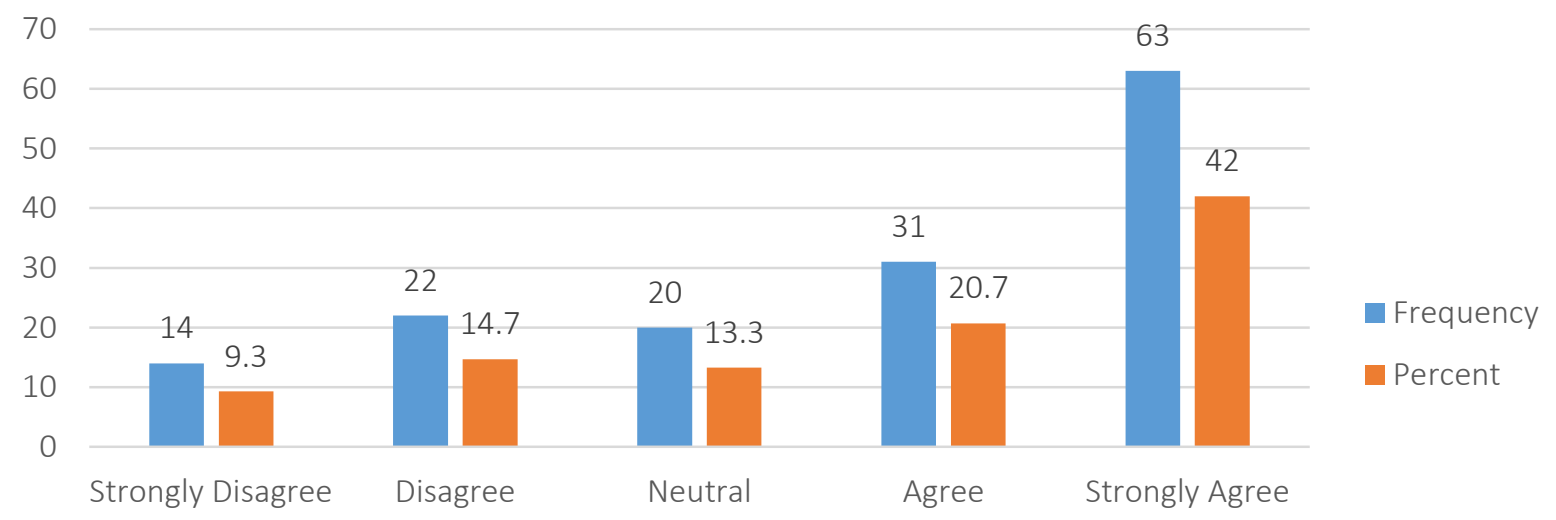

Figure 5. Technology adoption influences the adoption of MAPs 


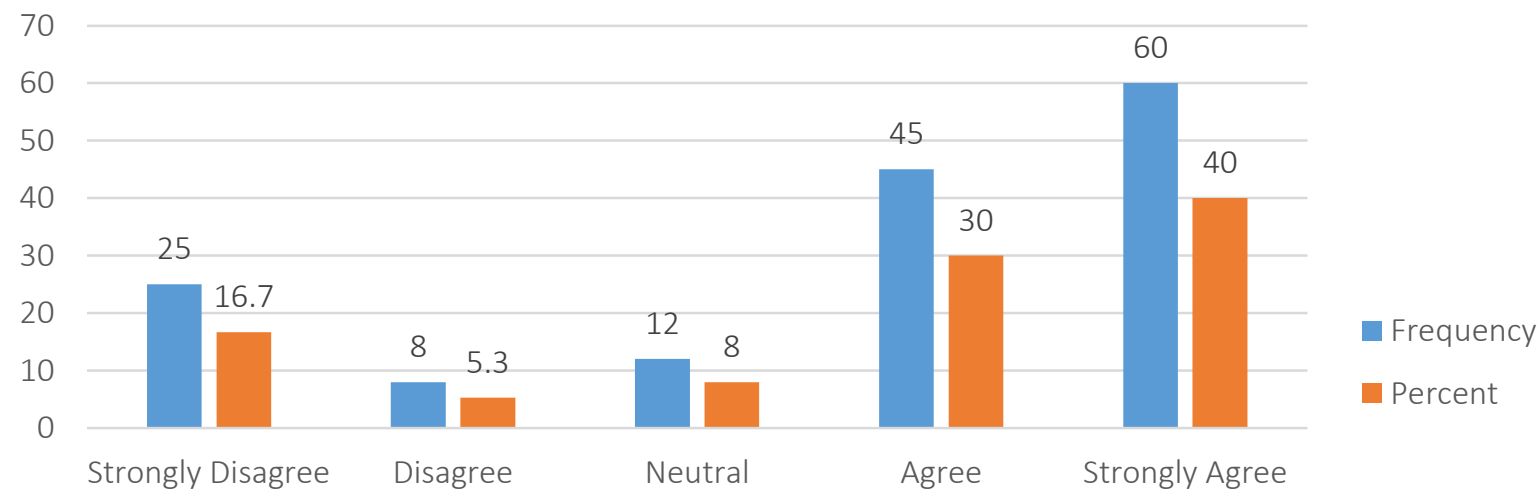

Figure 6. Technology adoption and the usage of MAPs are key innovative strategies for business growth

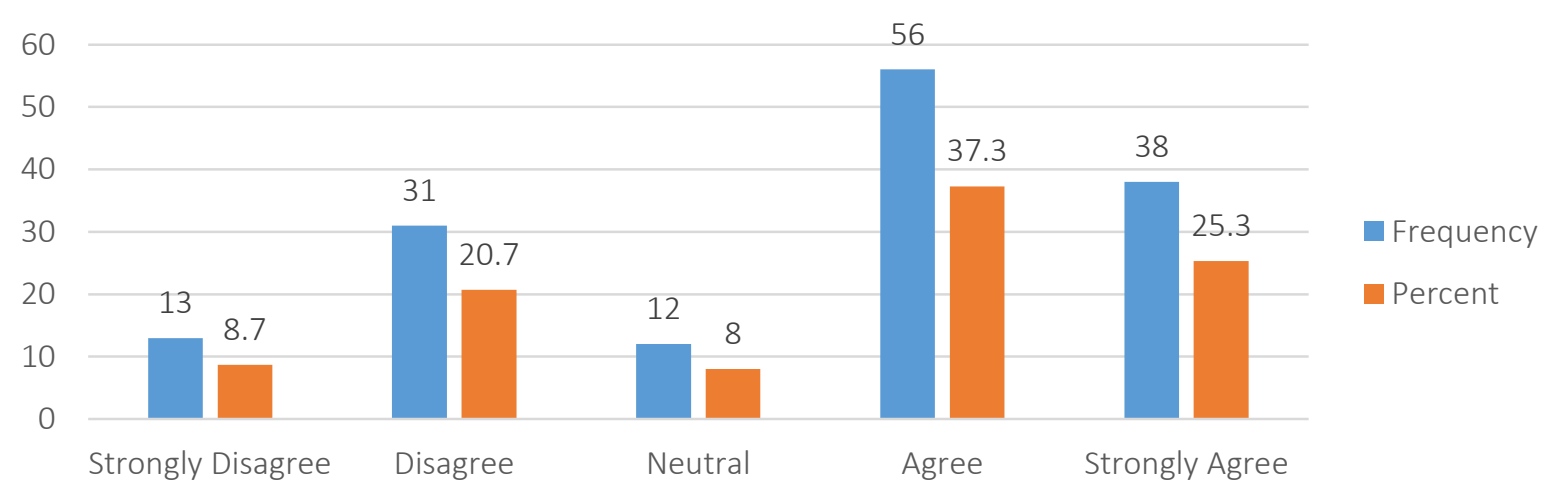

Figure 7. The inability to adopt MAPs impedes on business innovation

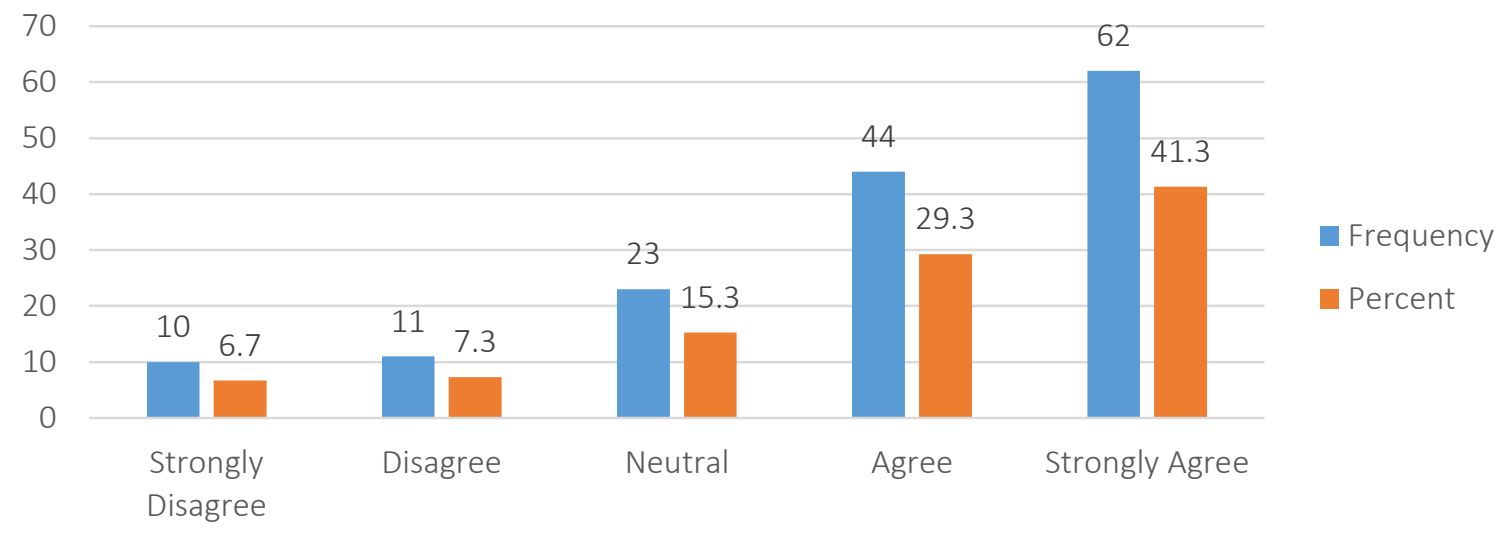

Figure 8. Business innovation can be obtained using relevant MAPs

effect on business innovation and deny the realization of business sustainable growth. These findings are true in the sense that business innovation can be obtained in different ways, as long as the integration improves the enterprise's current operations.

As reflected in Figure 8, a significant number of the respondents, $62(41.3 \%)$ and $44(29.3 \%)$, strongly agreed and agreed that business innovation can be obtained using relevant MAPs. Few respondents, 23 (15.3\%), were neutral, with only $7.3 \%$ of the respondents disagreeing with the statement. It is imperative to note that $70.6 \%$ of the respondents agreed that, for an enterprise to initiate business innovation, they will need to properly understand the type of MAPs to be 


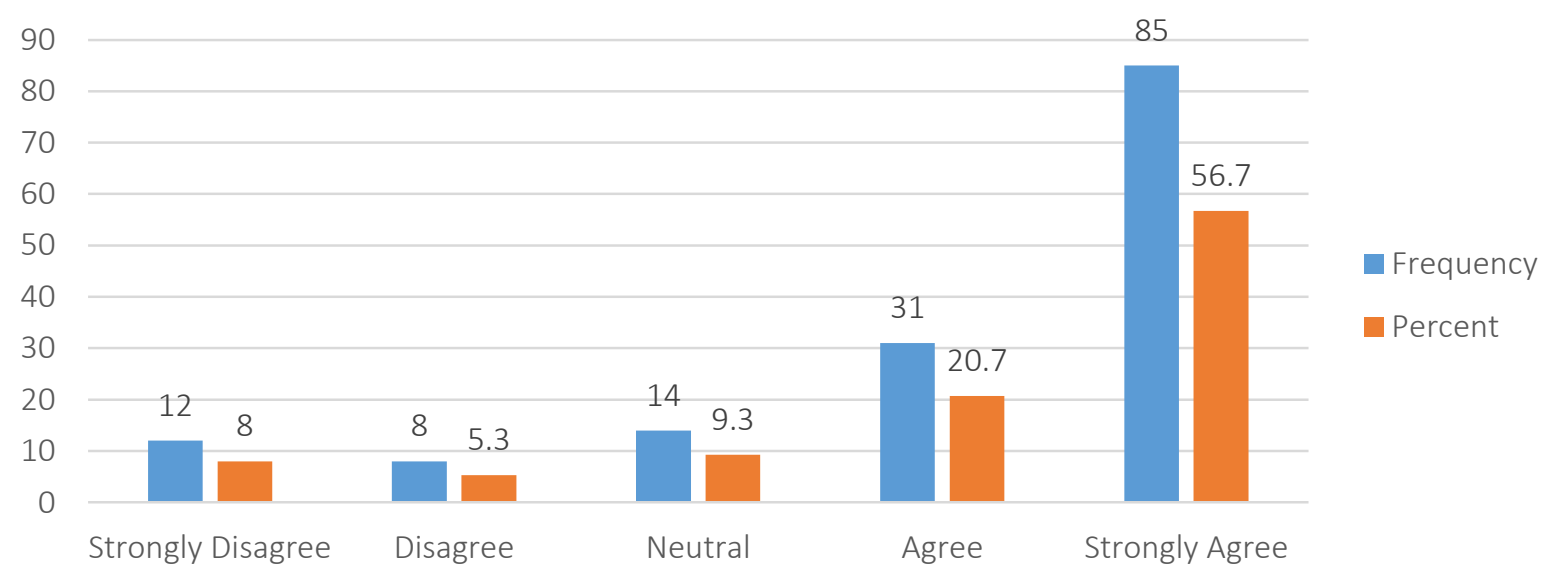

Figure 9. The adoption of relevant MAPs influences business operations

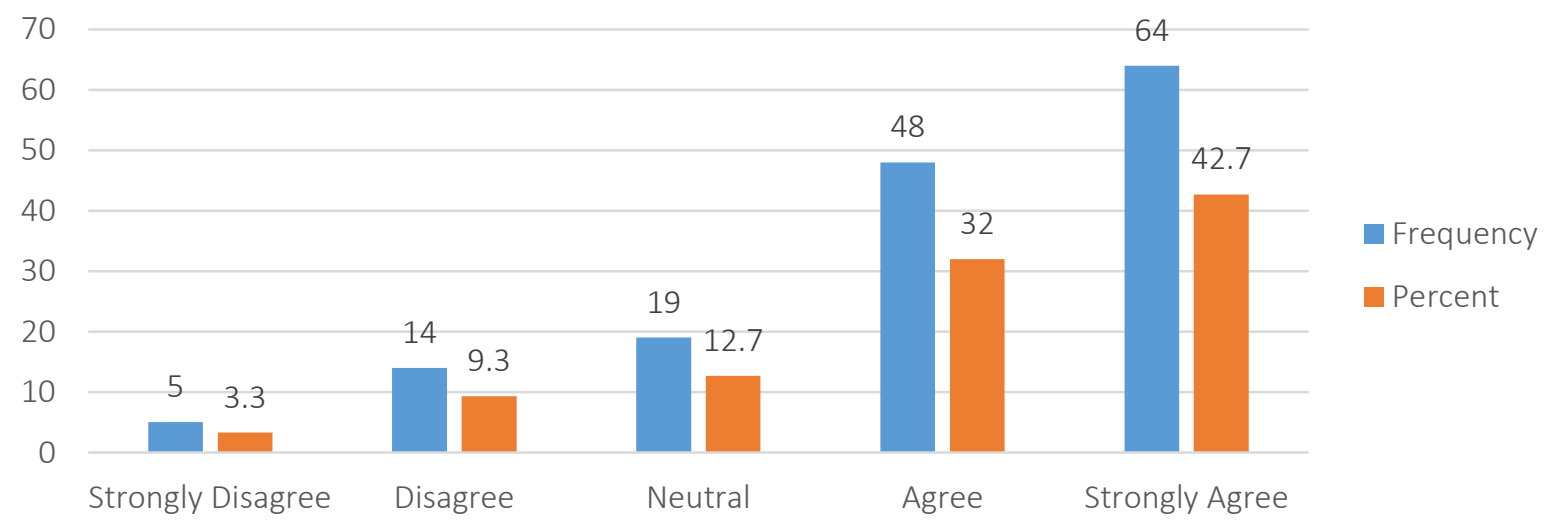

Figure 10. The adoption of MAPs serves as a strategic tool towards business innovation

adopted onto the enterprise operations and how best they can be utilized to influence business innovation. Therefore, these findings indicate that the adoption of MAPs may not influence business innovation, but the proper and coordinated usage of MAPs will support business innovation.

As reflected in Figure 9, a significant number of the respondents, 85 (56.7\%), strongly agreed, and 31 (20.7\%) agreed that the adoption of relevant MAPs influences business operations. A fewer number of respondents (13.3\%) disagreed with the statement, while only $9.3 \%$ were neutral. Based on these findings, it is clear that most (77.4\%) respondents valued the significance of adopting relevant MAPs and its tangible impact on business operations. Therefore, it is safe to say that the adoption of MAPs prioritizes the overall necessities needed for effective, efficient, and well-co-ordinated business operations. Therefore, this is forecasted at supporting business innovation and growth of the enterprise.

As reflected in Figure 10, a significant number of the respondents, $64(42.7 \%)$ and 48 (32.0\%), strongly agreed and further agreed that the adoption of MAPs serves as a strategic tool towards business innovation and growth. Based on these findings, the adoption of MAPs not only seeks to expedite operational business matters; however, it is seen as an essential catalyst to instigating business innovation, which is vitally significant to any enterprise with aspirations of growing. Fewer respondents $(12.6 \%)$ disagreed with the statement, with 19 (12.7\%) being neutral.

As reflected in Figure 11, a significant number of the respondents, 86 (57.3\%), strongly agreed, and $40(26.7 \%)$ further agreed that the adoption of MAPs improves competitive business advantage. Very few respondents (9.3\%) disagreed with the 


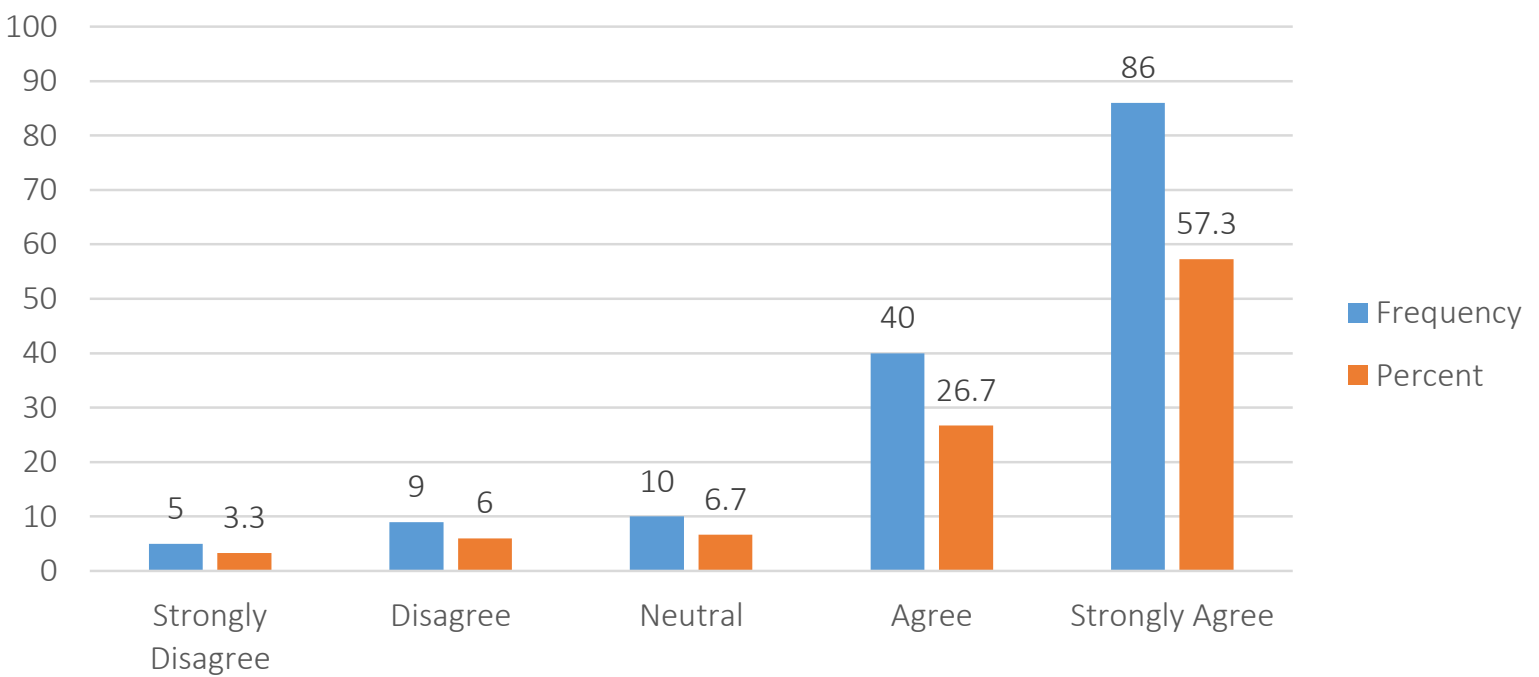

Figure 11. The adoption of MAPs improves competitive business advantage

statement, with $10(6.7 \%)$ being neutral. Based on these findings, $84 \%$ of the respondents identified the adoption of MAPs as a key strategic tool in gaining competitive advantage, which is enormously needed for business innovation and growth of an enterprise.

\section{CONCLUSION}

This research study's findings produce original results on the adoption of MAPs by SMEs in the eThekwini metropolitan, KwaZulu-Natal. Therefore, this study intended to examine the challenges of adopting MAPs as an innovative strategy towards business sustainability and to determine the business implications of adopting MAPs towards SMEs' sustainable growth. Based on the empirical findings, the study concludes that SMEs' owners and managers are fully aware of the impact and benefits of adopting MAPs. However, they are engulfed and oppressed by numerous challenges prohibiting them from successfully adopting and utilizing the integrated MAPs suitable for their business operation. The study concluded that the challenges hindering SMEs from utilizing MAPs as an innovative strategic tool were the enterprise age and years in operation, lack of education and training of owner/manager, shortage of skills, lack of government business incubation and technology adoption. These contributory factors were identified as essential aspects that SMEs needed to align and iron out before integrating MAPs as an innovative strategic tool.

It is further concluded that even though SMEs are considered the pillar of any country with the intention and aspiration of being recognized as an economic powerhouse, they are confronted by challenges that extend beyond their reach. Thus, recognizing and depicting these challenges in plain sight might help SMEs formulate informed strategies that would help support their quest to be innovative and attain sustainable business growth through the integration of MAPs.

\section{RECOMMENDATIONS}

As per the empirical findings of this study, the following recommendations have been formulated to provide awareness and shed light on the significant role of MAPs towards business innovation and the sustainable growth of an enterprise. It is recommended that SMEs should prioritize the extensive usage of MAPs regardless of the age or years of experience the firm has on the market. This is because MAPs can be easily integrated and be incorporated with transformations undergoing within the enterprise. 
Small businesses need to invest in technological advancement as many scholars have lauded it as an injection to achieving innovation and sustainable growth heavily. This study further sees technology adoption and the adoption of MAPs as fundamental strategic tools for instigating rapid innovation and competitive advantage achievement. This is predicted to have a positive and lasting impact on business innovation and the sustainable growth of an enterprise. SMEs' need to bolster their innovative culture if they are serious about competing and surviving within this congested and contested business environment.

It is further recommended that small businesses should start prioritizing skills development to help them cope with the turbulent and intricate business environment. Awareness and educational training can help improve small business owners and managers with the needed information and training to efficiently and effectively manage their businesses. The investment in education and training can further afford small business owners and managers exposure to certain business practices (such as adopting MAPs) and innovative approaches that play a starring role in sustaining an enterprise. Therefore, owners and managers of SMEs must strengthen their educational levels to improve the awareness and adoption of MAPs within their enterprises. Furthermore, education and training in small businesses should be customary if they are to be responsive to customers' ever-changing social preferences and economic status.

This study further recommends that the government provide a proper and well-documented gazette reflecting the services and or support provided by government business incubators to small businesses. A proper monitoring and evaluation method should also be established by the respective business incubators to assess the services' effectiveness and or support they had provided to those particular enterprises. This study argues the concept of injecting money to SMEs without proper business incubation as this may be a cause for failure, which may ultimately result in premature termination of enterprises.

\section{AUTHOR CONTRIBUTIONS}

Conceptualization: Mbali Portia Msomi, Musawenkosi Ngibe, Luyanda Lorraine Bingwa.

Investigation: Luyanda Lorraine Bingwa.

Software: Luyanda Lorraine Bingwa.

Supervision: Mbali Portia Msomi.

Writing - original draft: Mbali Portia Msomi, Musawenkosi Ngibe.

Writing - review \& editing: Musawenkosi Ngibe, Luyanda Lorraine Bingwa.

\section{REFERENCES}

1. Abel-Maksoud, A. (2011). Management accounting practices and managerial techniques in manufacturing firms: Egyptian evidence. Management and Financial Accounting, 3(3), 237254. Retrieved from https:// www.researchgate.net/publication/281998860_Management_accounting_practices_and_managerial_techniques_in_manufacturing_firms_Egyptian_evidence

2. Abor, J., \& Quartey, P. (2010). Issues in SME development in Ghana and South Africa. International Research Journal of Finance and Economics, 39(6),
215-228. Retrieved from http:// connection.ebscohost.com/c/ articles/50746389/issues-smedevelopment-ghana-south-africa

3. Agwa-Ejon, J., \& Mbohwa, C. (2015). Financial challenges faced by SMMES in Gauteng South Africa. In International Association for Management of Technology IAMOT 2015 Conference Proceedings (pp. 520534).

4. Ahmad, K., \& Mohamed Zabri, S. (2015). Factors explaining the use of management accounting practices in Malaysian medium-sized firms. Journal of
Small Business and Enterprise Development, 22(4), 762-781. https://doi.org/10.1108/JSBED-04-2012-0057

5. Amoako, G. (2013). Accounting practices of SMEs: A case study of Kumasi Metropolis in Ghana. International Journal of Business and Management, 8(24), 73-83. https://doi.org/10.5539/ijbm. v8n $24 \mathrm{p} 73$

6. Armitage, H., Webb, A., \& Glynn, J. (2016). The use of management accounting techniques by small and medium-sized enterprises: a field study of Canadian and 
Australian practice. Accounting Perspectives, 15(1), 31-69. https:// doi.org/10.1111/1911-3838.12089

7. Åström, K. J. (2016). National Bureau of Economic Research Workshop on Stochastic Control and Economic Systems, Princeton 1972. Department of Automatic Control, Lund Institute of Technology (LTH).

8. Ayandibu, A. N. (2019). Constraints that hinder the sustainability of small businesses in Durban, South Africa. Journal of Review on Global Economics, 8, 1402-1408. Retrieved from http:// www.lifescienceglobal.com/pms/ index.php/jrge/article/view/6282

9. Banker, D., Mashruwala, \& Tripathy, A. (2014). Does a differentiation strategy lead to more sustainable financial performance than a cost leadership strategy? Management Decision, 52, 872-896. Retrieved from https://www.researchgate. net/publication/274048942 Does_a_differentiation_strategy_ lead_to_more_sustainable_financial_performance_than_a_cost_ leadership_strategy

10. Bureau of Economic Research. (2016). Retrieved September 14, 2020, from https://www.ekon.sun. ac.za/ber

11. Bhoganadam, S., Rao, N., \& Rao, D. (2017). A study on issues and challenges faced by SME's: A literature review. Research Journal of SRNMC, 1, 48-56.

12. Cant, M. (2012). Challenges faced by SME's in South Africa: Are marketing skills needed? International Business and Economics Research Journal, 11(10), 1107-1116. Retrieved from https://www.semanticscholar. org/paper/Challenges-Faced-BySME's-In-South-Africa\%3A-AreCant/d4c7ff9282a556cb966f765b5 591829bdd6ae2b8

13. Chell, E. (2013). Review of skill and the entrepreneurial process. International Journal of Entrepreneurial Behaviours and Research, 19(1), 6-31. https://doi. org/10.1108/13552551311299233

14. Chugtai, M., \& Alam, I. (2014). Small and medium enterprises as engine in economic growth of Pakistan: an empirical analysis. Research Journal of Economic and Business Studies, 3(10), 4551. Retrieved from https://pdfs. semanticscholar.org/072b/99e46 9ea68c1c9a1957de8cdcd625d0ea f9f.pdf

15. CIMA. (2009). Research report: management accounting tools for today and tomorrow. Retrieved July 25,2020 , from http://www. cimaglobal.com/Documents/ Thought_leadership_docs/ CIMA\%20Tools\%20and\%20Techniques\%2030-11-09\%20PDF.pdf

16. CIMA. (2015). Management accounting tools for today and tomorrow. United Kingdom: CIMA Publishing.

17. Department of Trade and Industries, (2018). Retrieved September 14, 2020, from https:// www.gov.za/search?search_query= small+business+failure+rate

18. Fin24. (2017). Why SMEs have the potential to transform the economy. Retrieved July 17, 2020, from https://www.news24.com/fin24/ companies/retail/why-smes-havethe-potential-to-transform-theeconomy-20171030

19. Gakure, R., Ngugi, P., Waititu, A., \& Keraro, V. (2013). Effect of entrepreneurial skills on the sustainability of small and medium family enterprises after the exit of the founders. International Journal of Management and Business Studies, 3(2), 11-24. Retrieved from https:// www.semanticscholar.org/paper/ Effect-of-Entrepreneurial-Skillson-the-of-Small-of-Gakure-Ngugi/e29c73a25a6ef7256fb4b5d2a8f31c813811cbda

20. Halme, M., \& Korpela, M. (2014). Responsible innovation towards sustainable development in Small and Medium-Sized Enterprises: a resource perspective. Business Strategy and the Environment 23, 547-566. Retrieved from https://www.researchgate.net/ publication/264406293_Responsible_Innovation_Toward_Sustainable_Development_in_Small_and Medium-Sized_Enterprises_a_Resource_Perspective
21. Hansen, E., \& Schaltegger, S. (2016). The sustainability balance scorecard: a systematic review of architectures. Journal of Business Ethics, 133(1), 193-221. Retrieved from https://link.springer.com/article/10.1007/s10551-014-2340-3

22. Hoeppli, T. (2012). The Contribution of Small-and Medium-Sized Practices to the South African Economy and They Face. Retrieved March 31, 2020, from http://www.saipa.co.za/ articles/229902/contributionsmall-and-medium-sized-practices-smps-south-africa-economyand-callen

23. Hussein, A. (2018). Adoption, importance and barriers to the implementation of contemporary management accounting practices: Evidence from Egypt. Accounting and Finance Research, 7(1), 192213. Retrieved from http://www. sciedu.ca/journal/index.php/afr/ article/view/12612

24. International Leadership Development Programme. (2014). Retrieved September 14, 2020, from https://www.wrseta.org.za/ ILDP_2014/main.html

25. Jere, M., Jere, A., \& Aspeling, J. (2014). Informal and SMME retailers in South Africa. Retrieved April 1, 2020, from http://wrlc.org. za/wp-content/uploads/2014/12/ Informal-and-SMME-retailers-inSA-Drivers-and-Barriers.pdf

26. Jili, N., Masuku, M., \& Selepe, B. (2017). SMMEs promoting local economic development (LED) in UMlazi local Municipality, KwaZulu-Natal. African Journal of Hospitality, Tourism and Leisure, 6(1), 1-10. Retrieved from https://www.semanticscholar.org/ paper/SMMEs-promoting-LocalEconomic-Development-(-LED)-Masuku-Selepe/aedb4c16c60c0b3e15b87132d528416722e0785f

27. Johnstone, L. (2020). A systematic analysis of environmental management systems in SMEs: Possible research directions from a management accounting and control stance. Journal of Cleaner Production, 244, 1-13. https://doi. org/10.1016/j.jclepro.2019.118802 
28. Karedza, G., Sikwila, M., Mpufu, T., \& Makurumidze, S. (2014). An analysis of the obstacles to the success of SMEs in Chinhoyi Zimbabwe. European Journal of Business and Management, 6(6), 38-42. Retrieved from https:// www.iiste.org/Journals/index.php/ EJBM/article/view/11123

29. Keskin, H., \& Şentürk, C. (2010). The importance of Small and Medium-Sized Enterprises (SMEs) in economies: SWOT Analysis of the SME Sector in Turkey and Albania. Academic Review of Economic and Administrative Sciences, 3, 116-132.

30. Kogabayev, T., \& Maziliauskas, A. (2017). The definition and classification of innovation. Holistica, 8(1), 59-72. Retrieved from https://www.researchgate. net/publication/318180953_The_ definition_and_classification_of_ innovation

31. Kusi-Sarpong, S., Bai, C., Sarkis, J., \& Wang, X. (2015). Green supply chain practices evaluation in the mining industry using a joint rough sets and fuzzy TOPSIS methodology. Resources Policy, 46, 86-100. https://doi.org/10.1016/j. resourpol.2014.10.011

32. Kraus, J. (2017). What is cocoa sustainability? Mapping stakeholders socio-economic, environmental, and commercial constellations of priorities. Enterprise Development and Microfinance, 28(3), 220-249. Retrieved from https://www. researchgate.net/publication/320019657_What_is_cocoa_ sustainability_Mapping_stakeholders'_socio-economic_environmental_and_commercial_constellations_of_priorities

33. Malagueño, R., Lopez-Valeiras, E., \& Gomez-Conde, J. (2018). Balanced scorecard in SMEs: effects on innovation and financial performance. Small Business Economics, 51(1), 221-244. https:// doi.org/10.1007/s11187-0179921-3

34. Mahembe, E. (2011). Literature review on small and medium enterprises' access to credit and support in South Africa. Pretoria, South Africa: National Credit Regulator (NCR): Underhill Corporate Solutions.

35. Maziriri, E., \& Mapuranga, M. (2017). The impact of Management Accounting Practices (MAP's) on the Business Performance of Small and Medium Enterprises within the Gauteng Province of South Africa. Journal of Accounting and Management, 7(2), 12-25. Retrieved from https://www.researchgate.net/ publication/320386672_The_Impact_of_Management_Accounting_Practices_Maps_on_the _ Business_Performance_of_Small_ and_Medium_Enterprises_within_ the_Gauteng_Province_of_South_ Africa

36. Moorosi, P. (2014). Constructing a leader's identity through a leadership development programme: An intersectional analysis. Educational Management Administration \& Leadership, 42(6), 792-807.

37. Msomi, M., Ngibe, M., \& Nyide, C. (2019). Factors Influencing the Adoption of Management Accounting Practices (MAPs) by Manufacturing Small and Medium Enterprises (SMEs) in Durban, Kwazulu-Natal. International Journal of Entrepreneurship, 23(4), 1-18. Retrieved from https://www.researchgate.net/ publication/340967874_FACTORS_INFLUENCING_THE_ ADOPTION_OF_MANAGEMENT_ACCOUNTING_PRAC TICES_MAPs_BY_MANUFACTURING_SMALL_AND_MEDIUM_ENTERPRISES_SMEs_IN_ DURBAN_KWAZULU-NATAL

38. Nandan, R. (2010). Management Accounting Needs of SMEs and the Role of Professional Accountants: A Renewed Research Agenda. Journal of Management Accounting Research, 8(1), 65-78. Retrieved from https://www.researchgate.net/ publication/265237891_Management_Accounting_Needs_of_SMEs_and_the_Role_of_Professional_Accountants_A_Renewed_ Research_Agenda
39. Ngibe, M., \& Lekhanye, L. (2019). Critical Factors influencing innovative leadership in attaining business innovation: a case of manufacturing SMEs in KwaZuluNatal. International Journal of Entrepreneurship, 23(2), 1-20. Retrieved from https://www. abacademies.org/abstract/criticalfactors-influencing-innovativeleadership-in-attaining-businessinnovation-a-case-of-manufacturing-smes-in-kwaz-8342.html

40. Ngibe, M., \& Lekhanye, L. (2019). Innovative leadership in South African manufacturing Small Medium Enterprises within KwaZulu-Natal. Journal of Contemporary Management, 16(2), 300-330. Retrieved from https:// journals.co.za/content/journal/10520/EJC-191ca35fd3

41. Nnawetanma, C. (2020). SMEs: How to attract fund from banks, investors, donors. Retrieved July 17, 2020, from https://nairametrics. com/2020/03/24/smes-how-to-attract-fund-from-banks-investorsdonors/

42. OECD. (2017). Enhancing the contributions of SMEs in a global and digitalised economy. Retrieved July 17, 2020, from https://www. oecd.org/industry/C-MIN-20178-EN.pdf

43. Otley, D. (2016). The contingency theory of management accounting and control: 19802014. Management Accounting Research, 31, 45-62. https://doi. org/10.1016/j.mar.2016.02.001

44. Oyelana, A., \& Smith, W. (2015). An investigation into challenges as well as means to overcome challenges facing small and medium enterprises (SMEs) in South Africa. Journal of Economics, 6(2), 177-188. Retrieved from https://pdfs.semanticscholar.org/ e5d1/af36653d18460e58923f9eb83f08c2671755.pdf

45. Pantelica, D., Sakalb, M., \& Zehetner, A. (2016). Marketing and sustainability from the perspective of future decisionmakers. South African Journal of Business Management, 47(1), 37-47. Retrieved from https:// 
www.researchgate.net/publication/304943484_Marketing_and_ sustainability_from_the_perspective_of_future_decision_makers

46. Pavlatos, O., \& Kostakis, H. (2015). Management accounting practices before and during economic crisis: Evidence from Greece. Advances in Accounting, 31(1), 150-164. https://doi.org/10.1016/j. adiac.2015.03.016

47. Pavlatos, O., \& Kostakis, H. (2018). Management accounting innovations in a time of economic crisis. The Journal of Economic Asymmetries, 18, 1-12. https://doi. org/10.1016/j.jeca.2018.e00106

48. Pedroso, E., \& Gomes, C. (2020). The effectiveness of management accounting systems in SMEs: a multidimensional measurement approach. Journal of Applied Accounting Research, 21(3), 497515. https://doi.org/10.1108/ JAAR-05-2018-0059

49. Razavi, S., \& Attarnezhad, O. (2013). Management of organisational innovation. International Journal of Business and Social Sciences, 4(1), 226-232.

50. Reyad, S., Al-Sartawi, A., Badawi, S., \& Hamdan, A. (2019). Do entrepreneurial skills affect entrepreneurship attitudes in accounting education? Higher education, skills and work-based learning. Retrieved July 31, 2020, from https://doi.org/10.1108/HESWBL-01-2019-0013.

51. SEDA. (2018). SMME quarterly update: 1st Quarter 2018. Retrieved April 1, 2020, from http://www.seda.org.za/Publications/Publications/SMME\%20 Quarterly\%202018-Q1.pdf

52. Stock, T., Obenaus, M., Slaymaker, A., \& Seliger, G. (2016). A model for the development of sustainable innovations for the early phase of the innovation process. Procedia Manufacturing, 8, 215-222. https://doi.org/10.1016/j.promfg.2017.02.027

53. Surnani, C. (2013). Management Accounting Practices and the Role of Management Accountant: Evidence from Manufacturing
Companies throughout Yogyakarta, Indonesia. Review of Integrative Business and Economics Research, 2(2), 616-626. Retrieved from https://sibresearch.org/ uploads/3/4/0/9/34097180/riber_b13-243_616-626.pdf

54. Timmis, C. (2019). The state of small businesses in South Africa: New report reveals surprising optimism. Retrieved February 25, 2020, from https://www.heavychef. com/articles/2019/5/20/a-guideto-the-current-state-of-smallbusinesses-in-south-africa

55. Trust, F. (2015). Financial access and SME size in South Africa. Retrieved March 31, 2020, from http://www.finmark.org.za/ wp-content/uploads/2016/01/ Rep_Financial-Access-and-SMESize-in-SA_Dec2015-1.pdf

56. Turton, N., \& Herrington, M. (2012). Global Entrepreneurship monitor 2012 South Africa. Cape Town: Global Entrepreneurship Research Association.

57. Turyahikayo, E. (2015). Challenges faced by small and medium enterprises in raising finance in Uganda. International Journal of Public Administration and Management Research (IJPAMR), 3(2), 21-33.

58. Uturyte-Vrubliauskiene, L., \& Linkevicius, M. (2011). Innovative marketing decision drivers in business activities: a perspective direction of research. Intellectual Economies, 5(3), 445-459. Retrieved from https://www3. mruni.eu/ojs/intellectual-economics/article/view/722

59. Wu, K., Liao, C., Tseng, M., \& Chou, P. (2015). Understanding innovation for sustainable business management capabilities and competencies under uncertainty. Sustainability, 7, 13727-13760. Retrieved from https://www.researchgate.net/ publication/282821882_Understanding_Innovation_for_Sustainable_Business_Management_Capabilities_and_Competencies_under_Uncertainty

60. Zawawi, N., Wahab, S., ALMamun, A., Yaacob, A., Samy, N., \& Fazal, S. (2016). Defining the concept of innovation and firm innovativeness: A critical analysis from Resource-Based view perspective. International Journal of Business and Management, 11(6), 87-94. Retrieved from https://www.researchgate.net/ publication/303521736_Defining_the_Concept_of_Innovation_ and_Firm_Innovativeness_A_ Critical_Analysis_from_ResorceBased_View_Perspective

61. Zondo, R. (2016). The influence of entrepreneurship ecosystem for sustainable growth on the rural small and micro retail businesses: case study. International Journal of Innovative Research and Development, 5(12), 218-225. Retrieved from http://openscholar. dut.ac.za/handle/10321/2282 